\section{Fox Sparrows and Conservation}

\author{
By R. D. Symons
}

Among the birds of the Northwestern Peace River, I must mention one whose song par excellence greets our ears with each recurrent spring -- The Fox Sparrow's clear flute-like melody, "Sweet - on the radio - Sweet, Sweet, sweet," seems to say from its perch atop a willow bush and then, thrasherlike, dives into the scrub. As the song of the Meadowlark is to the prairie, so is the morning greeting of the Fox Sparrow to us in the open Park Lands.

I hope we can conserve these birds along with the many others which visit us each year -- but it will not be easy in the case of some species.

So-called progress, led by an army of bulldozers, will inevitably march in and destroy a good deal of country and crowd certain species out, as has always happened. We shall see dust blowing where now the wild Rye Grass and Indian Paint Brush wave, and the tent beside the wagon, the blue smoke curling heavenward. The wild free song of the Fox Sparrow will become, perhaps, only a memory to be stored away with similar memories of a still earlier day -- the saddle horse cropping the curly prairie grass; the glint of a bright slough and the cries of the marsh birds -- the cattle bedded down and only a buzzard screaming overhead.

Few of us know the value of a thing until we loose it, and to the bird lovers of the "Blue Jay" I say yours is the happiest lot of any in the West, for that which inspires you, that which is all poetry, all drama, all music, is yours every day of the year. Good Luck to you

\section{Weird Screams}

\section{Laurence Beckie}

On January 2nd a Snowy Owl was sitting on the snow in our stubble a few hundred yards from our house. As I listened and looked it gave out many weird screams which sound much like those of the Horned Owl. A flock of partridges a short distance from the owl were giving off frightened clucks, as a mother hen does to warn her chicks when mice are around.

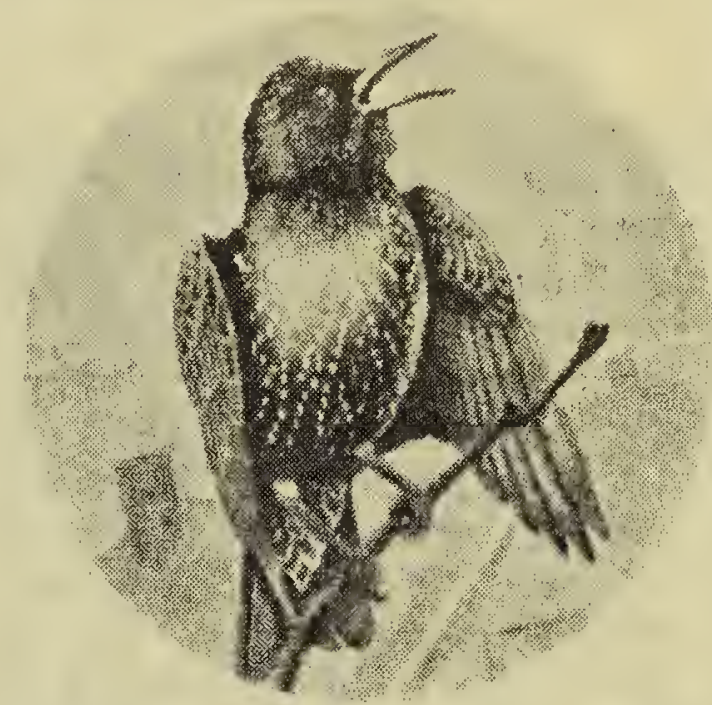

\section{European Starling}

By Clarissa Stewart, Fairy Hill, Sash.

One sharp November morning in 1947 the man in the house came in from the barn with something held care fully in his mittened hands. "found it on the pig's back", he said, uncovering a strange bird about the size of our western blackbird. The strangeness of the bird lay in its coloring. Its feathers had a groundwork of rusty black, if I remember correctly, entirely, speckled with lightish spots. We had never seen anything like it here in the Qu'Appelle Valley, which is a favorite resort for birds from early spring to late a utumn.

We placed it in a padded box for warmth and scattered crumbs for it, but it must have been too far go ne when it found the pig's back; for in a short time it succumbed.

I placed it in a cardboard box and mailed it to the Department of Agriculture in saskatoon for identification. They reported it to be a European Starling in its wi nter plumage, and said it was only the second one they had known in these northern regions.

In October last, while driving along our valley road I saw two of these bespeckled birds on the wire fence. They did not move as I passed them and there was no mistaking their distinctive coloration. They were exactly like the other one. I wonder if they are becoming more frequent visitors or habitues of the prairie west. 